\title{
POLA KEJADIAN HEMATOMA SUBDURAL PADA BAYI YANG DIRAWAT DI RUANG RAWAT INTENSIF ANAK RUMAH SAKIT HASAN SADIKIN
}

\author{
Enny Harliany Alwi \\ Bagian Ilmu Kesehatan Anak \\ Fakultas Kedokteran Universitas Padjadjaran/Rumah Sakit Hasan Sadikin Bandung
}

\begin{abstract}
ABSTRAK
Hematoma subdural (HSD) merupakan keadaan yang sering dijumpai pada bayi dan anak kecil dengan prognosis yang buruk. Sebagian besar penelitian menghubungkan HSD dengan cedera bukan kecelakaan. Dengan tujuan untuk mengetahui karakteristik hematoma subdural pada bayi kurang dari 1 tahun, telah dilakukan penelitian retrospektif pada bayi usia kurang dari 1 bulan dengan diagnosis HSD yang dirawat di PICU RS Dr. Hasan Sadikin antara Januari 2000 - Desember 2003. Bayi usia kurang dari 1 bulan atau HSD setelah intervensi bedah saraf, dikeluarkan dari penelitian. Terdapat 14 bayi yang memenuhi keriteria inklusi, terdiri dari 5 (36\%) perempuan dan 9 $(64 \%)$ laki-laki, terbanyak pada usia 1 bulan (57\%). Anemia terdapat pada semua kasus, trombosit normal kecuali 1 kasus trombositopenia $\left(53.000 / \mathrm{mm}^{3}\right)$. PT memanjang pada $9(100 \%)$ kasus, PTT pada $5(56 \%)$ dari 9 kasus. Bilirubin total/direk meningkat pada $4(80 \%)$ dari 5 kasus, SGOT/SGPT meningkat pada $5(83 \%)$ dari 6 kasus. Dari 11 kasus, 9 $(82 \%)$ kasus IgG anti CMV positif dan 6 (55\%) kasus IgM anti-CMV positif. Kesimpulan, HSD dapat diakibatkan oleh berbagai macam sebab, sehingga diperlukan pemeriksaan menyeluruh untuk menyingkirkan adanya kekerasan pada anak. Peran infeksi CMV perlu dipertimbangkan sebagai salah satu penyebab HSD.
\end{abstract}

Kata kunci: Hematoma subdural, bayi

\section{SUBDURAL HEMATOMA PATERN IN INFANTS AT PEDIATRIC INTENSIVE CARE UNIT HASAN SADIKIN GENERAL HOSPITAL}

\begin{abstract}
Subdural hematoma (SDH) is a common condition in infancy and young children with a poor prognostic. The more studies related SDH with nonaccidental injury. With the aim to identify the characteristics of SDH in infants below 1 year, a retrospective study of infants below 1 year diagnosed as subdural hematoma who were admitted to PICU Hasan Sadikin General Hospital from Januari 2000 to Desember 2003 has been conducted. Infants less than 1 month and SDH developed after neurosurgery intervention were excluded. Fourteen infants met the inclusion criteria's, consisted of $5(36 \%)$ girls and $9(64 \%)$ boys, most of them were on 1 month of age (57\%). Anemia was found on all cases, thrombocyte normal except in 1 case thrombocytopenia $\left(53,000 / \mathrm{mm}^{3}\right)$. PT prolonged in $9(100 \%)$ cases and PTT in 5 (56\%) from 9 cases. Bilirubin total/direct elevated in 4 (80\%) from 5 cases, SGOT/SGPT elevated in 5 (83\%) from 6 cases. From 11 cases, $9(82 \%)$ cases were IgG anti-CMV positive and $6(55 \%)$ cases were IgM anti CMV positive. Conclusions, SDH can be caused by various etiologies, thus a comprehensive examinations to exclude child abuse are needed. The role of CMV infection should be considered as one of SDH etiology.
\end{abstract}

Key words: Subdural hematoma, infancy

\author{
Alamat Korespondensi: \\ dr. Enny Harliany Alwi \\ Bagian Ilmu Kesehatan Anak \\ Fakultas Kedokteran Unpad/Rumah Sakit Hasan Sadikin \\ Jl. Pasteur No. 3840161 \\ Telp: 08122329940
}




\section{PENDAHULUAN}

Hematoma subdural (HSD) merupakan keadaan yang sering dijumpai pada masa bayi dan anak. Di negara maju, insidens hematoma subdural 12,8/100.000 anak/tahun, dengan insidens pada bayi kurang dari 1 tahun sebesar 21/100.000 anak/tahun. ${ }^{1}$ Hematoma subdural mempunyai prognosis yang buruk, sebanyak $75 \%$ kasus meninggal atau hidup dengan gejala sisa neurologis yang berat. ${ }^{1-3}$

HSD pada bayi dan anak kecil dapat diakibatkan oleh berbagai macam sebab, antara lain: cedera (sengaja/tidak sengaja), komplikasi bedah saraf, kondisi perinatal, malformasi kranial, infeksi serebral, gangguan koagulasi dan hematologik, gangguan metabolik, dan gangguan biokemika. ${ }^{4}$ Infeksi cyto-megalovirus (CMV) kongenital dilaporkan dapat menyebabkan perdarahan intrakranial pada bayi baru lahir. ${ }^{5,6}$ Sebagian besar penelitian yang ada menghubungkan hematoma atau perdarahan subdural pada bayi dengan cedera bukan kecelakaan. ${ }^{1,2,78}$ Didapatkannya HSD tanpa adanya faktor penyebab perdarahan seperti koagulopati, meningitis atau trauma, menandakan adanya kekerasan pada anak dan diperlukan pemeriksaan lebih lanjut. ${ }^{9}$ Hal yang cukup menarik adalah sejumlah penelitian saat ini terus memperkecil peran kekerasan dalam terjadinya perdarahan subdural pada bayi. ${ }^{8}$

Selama tahun 2002-2003, di Pediatric Intensive Care Unit (PICU) RS Dr. Hasan Sadikin terdapat peningkatan jumlah bayi dan anak yang dirawat dengan diagnosis hematoma subdural. Sepengetahuan penulis, di Indonesia belum ada data mengenai kejadian HSD pada bayi dan anak. Oleh karena itu penelitian ini dilakukan dengan tujuan untuk mengetahui bagaimana karakteristik hematoma subdural pada bayi berusia kurang dari 1 tahun .

\section{METODE}

Dilakukan penelitian retrospektif, terhadap bayi berusia kurang dari 1 tahun yang dirawat di PICU RS Dr. Hasan Sadikin dari Januari 2000Desember 2003 dengan diagnosis hematoma subdural. Diagnosis HSD ditegakkan berdasarkan hasil pemeriksaan CT-scan. Bayi yang berusia kurang dari 1 bulan dan bayi dengan HSD yang terjadi setelah intervensi bedah saraf dikeluarkan dari penelitian ini.

Data diambil dari rekam medis, meliputi: identitas, usia, jenis kelamin, pemberian vitamin $\mathrm{K}$, gejala dan tanda klinis, pemeriksaan laboratorium yang terdiri dari darah rutin, partial thromboplastin time (PTT), prothrombin time (PT), tes fungsi hati, serologis untuk CMV, tindakan operasi, dan keadaan saat keluar dari rumah sakit.
HASIL

Selama periode Januari 2000 - Desember 2003 terdapat 1.200 bayi dan anak yang dirawat di PICU RS Dr. Hasan Sadikin. Dari 14 bayi yang memenuhi kriteria inklusi terdapat lima (36\%) bayi perempuan dan sembilan (64\%) bayi lakilaki, usia berkisar antara 1-4 bulan dengan jumlah kasus terbanyak pada usia 1 bulan yaitu sebanyak delapan orang (57\%).

Kejang merupakan keluhan terbanyak yang membawa bayi ke RS, terdapat pada enam $(43 \%)$ kasus, diikuti oleh penurunan kesadaran pada lima (36\%) kasus, dan terdapat dua $(14 \%)$ kasus dengan keluhan badan kuning (Tabel 1). Semua bayi datang dalam keadaan anemia dengan nilai hemoglobin rata-rata 6,85 $\mathrm{g} / \mathrm{dL}$ (rentang 3,7-11,7 $\mathrm{g} / \mathrm{dL}$ ), jumlah trombosit normal kecuali pada satu kasus didapatkan trombositopenia $\left(53.000 / \mathrm{mm}^{3}\right)$. Dari sembilan kasus yang diperiksa, PT memanjang pada semua kasus dan PTT memanjang pada lima $(56 \%)$ kasus. Gangguan fungsi hati yang dinyatakan dengan peningkatan kadar bilirubin total dan direk dapatkan pada empat ( $80 \%)$ dari lima bayi yang diperiksa, peningkatan kadar SGOT/SGPT didapatkan pada lima (83\%) dari enam bayi yang diperiksa, dan terdapat tiga bayi dengan peningkatan baik kadar bilirubin maupun SGOT/SGPT (Tabel 2). Ternyata dari sebelas kasus yang diperiksa, IgG anti-CMV positif pada sembilan (82\%) bayi, IgM anti-CMV positif pada enam (55\%) bayi, dan terdapat empat (36\%) kasus dengan IgG dan IgM positif.

Hasil CT-scan dapat dilihat pada Tabel 2. Tindakan operatif dilakukan pada 12 bayi, satu bayi mendapat penanganan konservatif karena kondisinya tak memungkinkan untuk tindakan operatif (gagal napas dengan terpasang ventilator) dan satu bayi tidak diizinkan untuk tindakan operatif dan dibawa pulang. Dari 12 bayi yang mendapat tindakan operatif, sebanyak $10(83 \%)$ bayi meninggalkan RS dalam keadaan hidup dan dua (17\%) bayi meninggal, sedangkan bayi dengan perawatan konservatif meninggalkan RS dalam keadaan hidup. Dari yang hidup, satu orang dapat diikuti perkembangannya dengan gejala neurologis berupa mikrosefalia dan palsi serebral.

\section{PEMBAHASAN}

Hematoma subdural sering didapatkan pada masa bayi, terutama pada satu tahun pertama kehidupan. ${ }^{1}$ HSD terjadi karena robeknya vena penghubung yang kecil, yang menghubungkan antara duramater dan pia araknoid. Perdarahan terutama terjadi di fisura interhemisfer dan sebagian kecil pada bagian konveks hemisfer. ${ }^{10}$ Hampir satu per lima HSD pada bayi dan anak kecil terjadi akibat kecelakaan yang tidak 
Tabel 1 Gambaran Klinis, Hematologis, dan Koagulasi pada Bayi Usia Kurang dari 1 Tahun dengan Hematoma Subdural

\begin{tabular}{|c|c|c|c|c|c|c|c|}
\hline $\begin{array}{l}\text { Kasus } \\
\text { No. }\end{array}$ & $\begin{array}{c}\text { Jenis } \\
\text { Kelamin }\end{array}$ & $\begin{array}{c}\text { Usia } \\
\text { (bulan) }\end{array}$ & $\begin{array}{c}\text { Keluhan } \\
\text { Utama }\end{array}$ & Gejala Klinis & $\begin{array}{c}\mathrm{Hb} \\
\text { (g/dL) }\end{array}$ & $\begin{array}{l}\text { Trombosit } \\
\left(\text { per } \mathrm{mm}^{3}\right)\end{array}$ & $\begin{array}{l}\text { PT/PTT } \\
\text { (detik) }\end{array}$ \\
\hline 1. & $P$ & 1 & BAB berdarah & $\begin{array}{l}\text { Pucat, UUB cembung, tegang, } \\
\text { pupil anisokor, hemiparesis sint }\end{array}$ & 8,3 & 160.000 & - \\
\hline 2 & $\mathrm{P}$ & 1 & Kejang & $\begin{array}{l}\text { Pucat, UUB cembung, tegang, } \\
\text { pupil anisokor }\end{array}$ & 7.0 & 490.000 & $>50 / 163,4$ \\
\hline 3. & L & 2 & Kejang & $\begin{array}{l}\text { Pucat, UUB cembung, tegang, } \\
\text { pupil anisokor, paresis }(+)\end{array}$ & 5,2 & 202.000 & $20,1 / 28,4$ \\
\hline 4. & $P$ & 4 & $\begin{array}{l}\text { Kejang, } \\
\text { trauma (+), } \\
\text { jatuh dari } \\
\text { gendongan }\end{array}$ & $\begin{array}{l}\text { Pucat, UUB datar, tegang, pupil } \\
\text { isokor }\end{array}$ & 7,7 & 53.000 & $18,8 / 20,1$ \\
\hline 5. & L & 1 & $\begin{array}{l}\text { Penurunan } \\
\text { kesadaran }\end{array}$ & $\begin{array}{l}\text { Pucat, UUB cembung, tegang, } \\
\text { pupil isokor }\end{array}$ & 6.9 & 315.000 & $48,7 / 42,2$ \\
\hline 6. & L & 2 & Kejang & $\begin{array}{l}\text { Pucat, UUB cembung, tegang, } \\
\text { pupil anisokor, ptosis kanan }\end{array}$ & 5,8 & 269.000 & - \\
\hline 7. & L & 2 & Kejang & $\begin{array}{l}\text { Pucat, UUB cembung, tegang, } \\
\text { pupil isokor }\end{array}$ & 5,5 & 212.000 & - \\
\hline 8. & L & 2 & Badan kuning & $\begin{array}{l}\text { Pucat, ikterik, UUB cembung, } \\
\text { tegang, pupil is okor }\end{array}$ & 4,6 & 484.000 & $>>>\mid>>>$ \\
\hline 9. & L & 1 & $\begin{array}{l}\text { Penurunan } \\
\text { kesadaran }\end{array}$ & $\begin{array}{l}\text { Pucat, UUB cembung, tegang, } \\
\text { pupil isokor }\end{array}$ & 3,7 & 195.000 & - \\
\hline 10. & $\mathrm{P}$ & 1 & $\begin{array}{l}\text { Penurunan } \\
\text { kesadaran, } \\
\text { kejang }\end{array}$ & $\begin{array}{l}\text { UUB cembung, tegang, pupil } \\
\text { isokor }\end{array}$ & 11,3 & 410.000 & - \\
\hline 11. & L & 1 & $\begin{array}{l}\text { Penurunan } \\
\text { kesadaran, } \\
\text { kejang }\end{array}$ & $\begin{array}{l}\text { Pucat, UUB cembung, tegang, } \\
\text { pupil isokor }\end{array}$ & 7,5 & 288.000 & $17,2 / 29,3$ \\
\hline 12. & L & 1 & $\begin{array}{l}\text { Penurunan } \\
\text { kesadaran } \\
\text { kejang }\end{array}$ & $\begin{array}{l}\text { Pucat, UUB cembung, tegang, } \\
\text { pupil isokor }\end{array}$ & 3,9 & 501.000 & $>120 />150$ \\
\hline 13. & L & 1 & $\begin{array}{l}\text { Penurunan } \\
\text { kesadaran }\end{array}$ & $\begin{array}{l}\text { UUB cembung, tegang, pupil } \\
\text { isokor }\end{array}$ & 11,7 & 351.000 & $16,3 / 31,1$ \\
\hline 14. & $\mathrm{P}$ & 2 & Badan kuning & $\begin{array}{l}\text { Pucat, ikterik, UUB datar, pupil } \\
\text { isokor }\end{array}$ & 6,8 & 465.000 & $>150 / 47,8$ \\
\hline
\end{tabular}

Keterangan:

$\mathrm{BAB}=$ buang air besar, $\mathrm{UUB}=$ ubun-ubun besar, $\mathrm{Hb}=$ hemoglobin,

$\mathrm{PT}=$ prothrombin time, $\mathrm{PTT}=$ partial thromboplastin time

Tabel 2 Gambaran Fungsi Hepar, Petanda Infeksi CMV, CT- Scan, dan Keadaan Saat Keluar RS pada Bayi Usia Kurang dari 1 Tahun dengan Hematoma Subdural

\begin{tabular}{|c|c|c|c|c|c|}
\hline $\begin{array}{l}\text { Kasus } \\
\text { No. }\end{array}$ & $\begin{array}{l}\text { Bilirubin } \\
\text { Total/Direk } \\
\text { (mg/dl) }\end{array}$ & $\begin{array}{c}\text { SGOT/SGPT } \\
(\mathrm{U} / \mathrm{L})\end{array}$ & $\begin{array}{c}\lg G \text { ant-CMV/lgM } \\
\text { anti-CMV }\end{array}$ & CT-scan & $\begin{array}{l}\text { Keadaan } \\
\text { keluar } \\
\text { RS }\end{array}$ \\
\hline 1. & $12,10 / 9,0$ & $232,4 / 272,1$ & $126,702(+) / 8,521(+)$ & HSD temporo-parietal kanan & Hidup \\
\hline 2. & $4,5 / 0,9$ & - & $0,156(-) / 0,495(+)$ & $\begin{array}{l}\text { HSD fronto-parietal kiri + perdarahan } \\
\text { intraserebral + perdarahan subaraknoid }\end{array}$ & Hidup \\
\hline 3. & - & $26 / 19$ & $76,4(+) /(-)$ & HSD temporo-parieto-oksipital kiri & Hidup \\
\hline 4. & - & - & $48,9(+) /(-)$ & HSD subakut fronto-temporo-parietal kiri & Hidup \\
\hline 5. & - & - & $3,7(+) /(-)$ & HSD subakut parietal kiri & Hidup \\
\hline 6. & - & & $152,6(+) / 2,105(+)$ & HSD fronto-temporo-parietal kiri & Hidup \\
\hline 7. & - & - & $0,948(+) / 0,975(+)$ & HSD fronto-parieto-oksipital kanan & Hidup \\
\hline 8. & $6 / 4,9$ & $107 / 74$ & - & HSD parieto-oksipital kanan & Pulang paksa \\
\hline 9. & - & - & $50,3(+) /(-)$ & $\begin{array}{l}\text { HSD subakut fronto-temporo-parieto- } \\
\text { oksipital kiri }\end{array}$ & Hidup \\
\hline 10. & - & $48 / 42$ & $8,5(+) / 2,727(+)$ & $\begin{array}{l}\text { HSD fronto-parieto-oksipital kanan + } \\
\text { parietal kiri + interhemisfer + ventrikel III }\end{array}$ & Hidup \\
\hline 11. & - & $118 / 50$ & $12,1(+) /(-)$ & HSD fronto-temporo-parietal kiri & Meninggal \\
\hline 12. & $11,76 / 4,11$ & $53 / 32$ & - & $\begin{array}{l}\text { HSD oksipital kiri + perdarahan } \\
\text { intraserebral + perdarahan } \\
\text { intraventrikuler + hidrosefalus }\end{array}$ & Meninggal \\
\hline 13. & $9,56 / 6,01$ & - & $(-) / 1,501(+)$ & HSD fronto-parieto-oksipital kiri & Hidup \\
\hline 14. & - & - & - & HSD parietal kiri & Meninggal \\
\hline
\end{tabular}

Keterangan:

$\mathrm{HSD}=$ hematoma subdural, $\mathrm{SGOT}=$ serum glutamic oxaloacetic transaminase, SGPT=serum glutamic pyruvic

transaminase, $\mathrm{CMV}=$ cytomegalovirus 


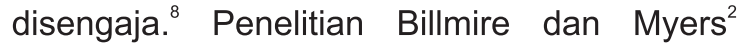
menemukan bahwa apabila trauma berat akibat kecelakaan disingkirkan, maka 95\% cedera intrakranial berat dan $64 \%$ dari keseluruhan cedera kepala pada bayi kurang dari 1 tahun disebabkan oleh kekerasan pada anak (child abuse). Anak yang mengalami kekerasan biasanya usianya lebih muda, lebih mungkin menderita HSD kronik, dan lebih mungkin disertai dengan cedera multipel. ${ }^{8}$ Pada penelitian ini, kemungkinan adanya kekerasan pada anak tidak dapat dibuktikan mengingat hanya satu kasus yang diketahui adanya riwayat trauma. Selain itu, adanya tanda cedera lain tidak didapatkan.

Koagulopati yang dihubungkan dengan terjadinya perdarahan intrakranial pada bayi di antaranya adalah hemofilia berat dan hipoprotrombinemia yang disebakan oleh defisiensi vitamin $\mathrm{K}^{7.8}$ Perdarahan intrakranial merupakan salah satu penyebab utama kegawatan dan kematian pada penderita hemofilia. Yoffe dan Buchanan ${ }^{11}$ mendapatkan perdarahan intrakranial pada penderita hemofilia terjadi pada usia 13 bulan, dan sebagian besar perdarahan terjadi pada subdural. Pada penelitian ini hasil pemeriksaan fungsi koagulasi tidak mendukung ke arah hemofilia. Pada lima kasus, PTT memanjang disertai dengan memanjangnya PT, sedangkan pada hemofilia nilai PT normal. PT dan PTT yang memanjang disertai dengan jumlah trombosit yang normal dapat dijumpai pada defisiensi vitamin K. Hasil penelitian Chaou dkk. ${ }^{12}$ timbulnya gejala perdarahan intrakranial pada bayi dengan defisiensi vitamin $\mathrm{K}$ paling sering pada usia 10-40 hari, dengan perbandingan antara laki-laki dan perempuan 2:1. Defisiensi vitamin $K$ pada bayi dapat disebabkan karena tidak mendapat suplemen vitamin $\mathrm{K}$ pada saat lahir, gangguan saluran cerna seperti diare, penggunaan antibiotik dan terutama terjadi pada bayi yang menyusui. Pada penelitian ini kemungkinan terjadinya HSD akibat defisiensi vitamin $\mathrm{K}$ perlu dipertimbangkan, hanya sayang data mengenai masukan vitamin $\mathrm{K}$ pada saat lahir dan keadaan lain yang dapat mengganggu masukan vitamin $\mathrm{K}$ tidak didapatkan. Kemungkinan lain koagulopati terjadi sebagai akibat trauma kepala, termasuk di antaranya adalah trauma kepala akibat kekerasan pada anak. Menurut Hymel dkk. ${ }^{13} \mathrm{PT}$ yang memanjang disertai adanya aktivasi koagulasi yang didefinisikan sebagai: peningkatan PT ( $\geq 16$ detik) tanpa adanya defisiensi vitamin $K$ atau penyakit hati, peningkatan PT dan PTT, atau peningkatan PT disertai dengan trombosit yang rendah, fibrinogen rendah, dan/atau adanya fibrin degradation product (FDP), berhubungan erat dengan adanya kerusakan parenkim otak. Pada penilitian ini, adanya riwayat trauma yang dapat dihubungkan dengan kejadian kekerasan pada anak hanya terdapat pada kasus nomor 4 saja.

Hal yang menarik pada penelitian ini, dari 11 bayi yang diperiksakan didapatkan lebih dari separuhnya positif IgG atau IgM anti-CMV, dan terdapat $36,4 \%$ yang positif keduanya. Pada bayi dengan infeksi CMV kongenital simtomatik akan didapatkan gejala anemia, trombositopenia, hiperbilirubinemia, limfositosis atipik, peningkatan transaminase serum, dan peningkatan protein cairan serebrospinalis. ${ }^{6}$ Perdarahan intrakranial pada infeksi CMV diyakini disebabkan oleh trombositopenia. ${ }^{5}$ Pada penelitian ini meskipun didapatkan hiperbilirubinemia pada empat dari lima bayi dan peningkatan SGOT/SGPT pada lima dari enam bayi yang diperiksa, tetapi jumlah trombosit pada seluruh bayi normal kecuali pada kasus dengan riwayat trauma. Untuk mengetahui apakah infeksi CMV mempunyai peran untuk terjadinya HSD pada penelitian ini, diperlukan pemeriksaan yang lebih lengkap mencakup riwayat perinatal, serologis anti-CMV ibu, dan bila memungkinkan PCR untuk mendeteksi DNA virus.

Keadaan akhir pada saat meninggalkan RS, dari 12 bayi yang dilakukan operasi kraniotomi evakuasi sebanyak $10(83 \%)$ bayi pulang dalam keadaan hidup. Sayangnya hanya satu bayi yang dapat diikuti perkembangannya dengan gejala sisa neurologis berupa mikrosefalia dan palsi serebral. Hasil penelitian Haviland dan Russel, ${ }^{3}$ sebanyak $54 \%$ anak dengan cedera bukan kecelakaan akan mengalami keterbatasan berat (ketergantungan total fisik dan mental), $34 \%$ dengan keterbatasan sedang (hemiparesis berat, kebutaan, keterlambatan perkembangan), dan $7,7 \%$ dengan keterbatasan ringan (hemiparesis dan kejang).

Sebagai kesimpulan, HSD merupakan suatu keadaan yang dapat diakibatkan oleh berbagai macam sebab. Oleh karena itu perlu dilakukan pemeriksaan yang teliti dan menyeluruh untuk menyingkirkan kemungkinan faktor kekerasan pada anak. Peran infeksi CMV dalam terjadinya HSD harus dipertimbangkan agar dapat dilakukan penanganan dini dan pencegahan pada bayi dengan faktor risiko.

\section{DAFTAR PUSTAKA}

1. Jayawant S, Rawlinson A, Gibbon F, Price J, Schulte J, Sharples P, dkk. Subdural hemorrhages in infants: population based study. BMJ. 1998;317:1558-61.

2. Billmire ME, Myers PA. Serious head injury in infants: accident or abuse?. Pediatrics. 1985;75: 340-2.

3. Haviland J, Russell RIR. Outcome after severe non-accidental head injury. Arch Dis Child. 1997;77:504-7. 
4. Kemp AM. Investigating subdural haemorrhage in infants. Arch Dis Child. 2002;86:98-102.

5. MCDonald JM, Raghuveer TS, D'Alessandro MP. Can congenital CMV infection lead to intracranial hemorrhage?. J Perinatol. 2001;21:402-4.

6. Leung AKC, Sauve RS, Davies HD. Congenital cytomegalovirus infection. J Nat Med Assoc. 2003;95:213-8.

7. Duhaime AC, Christian CW, Rorke LB, Zimmerman RA. Nonaccidental head injury in infants-the "Shaken-Baby Syndrome". N Engl J Med. 1998;338:1822-9.

8. Feldman $\mathrm{KW}$, Bethel $\mathrm{R}$, Shugerman RP, Grossman DC, Grady MS, Ellenbogen RG. The cause of infant and toddler subdural hemorrhage: a prospective study. Pediatrics. 2001;108:63646.
9. Morris MW, Smith S, Cressman J, Ancheta J. Evaluation of infants with subdural hematoma who lack external evidence of abuse. Pediatrics. 2000;105:549-53.

10. American Academy of Pediatrics. Shaken baby syndrome: rotational cranial injuries-technical report. Pediatrics. 2001;108:206-10.

11. Yoffe G, Buchanan GR. Intracranial hemorrhage in newborn and young infants with hemophilia. J Pediatr. 1988;113:333-6.

12. Chaou WT, Chou ML, Eitzman DV. Intracranial hemorrhage and vitamin $\mathrm{K}$ deficiency in early infancy. J Pediatr. 1984;105:880-4.

13. Hymel KP, Abshire TC, Luckey DW, Jenny C. Coagulopathy in pediatric abuse head trauma. Pediatrics. 1997;99:371-5. 